\title{
La crítica de la poesía lírica en la obra periodística de Larra
}

\author{
The Critique of Lyrical Poetry \\ in Larra's Articles
}

Pedro Larrea Rubio

University of Virginia

\section{RESUMEN}

Este artículo estudia las ideas estéticas de Mariano José de Larra sobre la poesía lírica, a través de todos los artículos en que Larra expone sus opiniones sobre el género y a través de sus artículos sobre literatura y sus críticas de obras líricas de su época, como las Poesías de Francisco Martínez de la Rosa, las Poesías de Juan Bautista Alonso y Blanca de J.F. Díaz.

Palabras Clave: Mariano José de Larra, poesía lírica, estética, crítica, artículos, Francisco Martínez de la Rosa, Juan Bautista Alonso, J. F. Díaz.

\section{ABSTRACT}

This article deals with Mariano José de Larra's aesthetical ideas on lyrical poetry, studying all the articles in which Larra shows his opinions on the genre, as well as his articles on literature and his critical writing on the lyrical poetry of his time, such as Francisco Martínez de la Rosa's Poesías, Juan Bautista Alonso's Poesías and J.F. Diaz's Blanca.

Key words: Mariano José de Larra, Lyrical Poetry, Aesthetics, Critical Writing, Articles, Francisco Martínez de la Rosa, Juan Bautista Alonso, J. F. Díaz.

De entre la ya inmensa bibliografía dedicada a Larra, los estudios sobre la crítica literaria de Fígaro sobresalen como uno de los puntos de atención a que más se han dedicado los especialistas. Ahora bien, no existe aún artículo, y mucho menos libro, dedicado específicamente a la relación crítica entre Larra y la poesía lírica. Pocos especialistas han apuntado hacia el estudio de la propia obra poética del autor ${ }^{1}$, de difícil recuperación para el canon poético del siglo XIX, y prácticamente ninguno se ha enfocado en la crítica de

\footnotetext{
${ }^{1}$ Es el caso de Escobar en su Los orígenes de la obra de Larra.
} 
Larra sobre la poesía lírica de sus contemporáneos ${ }^{2}$. Lo cierto es que frente a la continuada, comprometida y abundante crítica teatral que ejerció constantemente, Larra sólo dedicó tres artículos al análisis de dos obras líricas de su tiempo: las Poesías de Francisco Martínez de la Rosa, las Poesías de Juan Bautista Alonso y Blanca, de J.F. Díaz. Por otra parte, su artículo, muy comentado, Literatura. Rápida ojeada sobre la historia e índole de la nuestra. Su estado actual. Su porvenir. Profesión de fe ha empañado la atención hacia los tres artículos mencionados y para la mayor parte de la crítica se ha erigido en una especie de non plus ultra en cuanto a la atención de Fígaro sobre la lírica. Al mismo tiempo, no se ha interpretado dicho artículo desde el estudio de la poesía, sino que se ha interpretado generalmente como código literario, sobre todo aplicable a la crítica teatral de Larra. Esta falta de interés no sólo se debe a la poca atención sobre el particular de los críticos, sino en primer lugar al propio Larra. Con tres artículos de crítica poética, y algunos juicios más o menos generales sobre la lírica insertados en algunos otros artículos de índole distinta, Larra no escribió mucho más sobre el tema. Ahora bien, la perspectiva de los estudios genéricos sobre poesía lírica permite añadir una nueva lectura de, sobre todo, los artículos dedicados a la obra poética de Martínez de la Rosa y de Alonso para así aumentar siquiera levemente el espectro de la crítica literaria de Larra en una región, si bien limitada, aún por estudiar. En primer lugar, se desprende de la crítica literaria de Larra que el género lírico, frente al género dramático o los géneros en prosa, no era en manera alguna el género principal en que un escritor podía destacar. Para Larra:

La política, interés principal que absorbe y llena en el día todo el espacio que a la pública curiosidad ofrecen en sus columnas los periódicos, nos ha impedido hasta ahora señalar en el nuestro a la literatura el lugar que de derecho le corresponde. Pero no hemos olvidado que la literatura es la expresión, el termómetro verdadero del estado de la civilización de un pueblo, ni somos de aquellos que piensan con los extranjeros que al concluir nuestro siglo de oro expiró en España la afición a las bellas letras. (Larra, 1997: 427).

De sobra conocida y remarcada, la teoría literaria de Larra está presidida, sin duda, por esta idea de la trabazón inexcusable entre literatura y nación, entre producción literaria y encarnación de una cultura y su regeneración. Es bajo esta perspectiva que se debe considerar la escasa presencia de la lírica no sólo en la crítica de Larra sino en el panorama de las letras de su momen-

\footnotetext{
${ }^{2}$ Hay numeroso ejemplos de dicha desatención. En el Diccionario privado ni siquiera se recoge el término «Poesía» o «Lírica», sino el más general de «Literatura». Así ocurre también en Qué ha dicho verdaderamente... donde Armiño sólo analiza el artículo «Literatura» pasando por alto consideraciones sobre la lírica. Idéntico análisis incompleto sobre la cuestión ofrece Romero Mendoza en Siete ensayos... Aranguren, Azorín, Aymes, Kirkpatrick y otros sólo consideran la crítica teatral y novelística de Fígaro.
} 
to histórico. Voy a centrarme en aquellos tres artículos de crítica poética para señalar las ideas de Larra sobre el género. En primer lugar, no se debe olvidar que la obra literaria de Larra se inicia precisamente en el género lírico, si bien apenas cultivado, que pronto iba a abandonar por su plena labor periodística, teatral y novelística. No tenemos muchos datos al respecto, pero parece ser que Larra aceptó muy pronto su poco talento para la lírica, y un hombre cuyas ideas sobre la aristocracia del talento y cuya fustigación sistemática de la mediocridad literaria de su entorno fueron tan indelebles en su teoría estética no podía permitirse la dedicación a un género para el que de manera patente y temprana, y ejerciendo con maestría la crítica literaria desde el inicio de su carrera, bien supo que no estaba dotado ${ }^{3}$. Su propia creación poética es brevísima y sin apenas importancia para la historia del género en España ${ }^{4}$, y en contadas ocasiones, como veremos más adelante, se refiere Larra a sí mismo como poeta lírico, y siempre de manera implícita. He aquí otro fenómeno a destacar: la palabra «poeta» en los artículos de Larra aparece, con muy pocas excepciones, como sinónimo de «poeta dramático». No me detendré ahora en la importancia del género teatral en la España de principios del XIX, aunque no hay que perder de vista el hecho de que es en el teatro donde se consagran los autores de la época, género cuya producción y atención, tanto por parte de los literatos como por el público, superan indiscutiblemente a las del género lírico. No podía ser de otra manera entonces que Larra dedicase su pluma incansablemente a la crítica teatral, especialmente al recordar que el teatro es para nuestro escritor un instrumento de reforma social, y la literatura un elemento ideologizado ${ }^{5}$, incluida la lírica. Entonces, si un poeta así mencionado, sin adjetivación contigua es esencialmente un poeta dramático por antonomasia, no es de extrañar que el poeta lírico quede en segunda fila ante la atención de la crítica del momento. En las contadas ocasiones en que Larra se acerca al género, casi siempre se permite distraerse de la obra que está reseñando para considerar aspectos teóricos o sobre el status quo del género lírico, empezando con el artículo Poesías de don Francisco Martínez de la Rosa ${ }^{6}$. Larra distingue dos tipos de talento en cuanto al género poético. En primer lugar, los que ofrecen «preceptos de inspiración» y los

\footnotetext{
${ }^{3}$ Aún está por estudiarse este fenómeno, muy repetido en la historia literaria española, de escritores cuyos inicios están presididos por la lírica, género que no habría de darles la justa medida de su talento, y que pronto abandonan por la prosa, en concreto la novela, en que sobresalen. La lista sería larga, desde Cervantes hasta el mismo Larra, hasta llegar a Cela, Martín-Santos, e incluso las más recientes generaciones de prosistas españoles, como Joaquín Pérez Azaústre o Andrés Neuman.

${ }^{4} \mathrm{El}$ único que se detiene con interés en este punto inicial de la carrera literaria de Larra es José Escobar, que estudia de forma compendiada y general la producción poética de Fígaro en su Los orígenes de la obra de Larra.

${ }^{5}$ Véase el capítulo «Iniciación literaria; composición en verso» en Escobar.

${ }^{6}$ Publicado en Revista Española, núm. 91. Madrid, 3 de septiembre de 1833.
} 
que ingenian preceptos «didácticos». Entre los primeros se hallan los poetas en sí, y entre los segundos los autores de poéticas y preceptivas. Larra afirma que es imposible que en un mismo autor converjan ambos talentos, esto es, que un buen preceptista sea un buen poeta. Tras esta aseveración encontramos el primer elemento de las ideas poéticas de Larra: la fe en las poéticas, la creencia en que un código de normas pueden legislar la creación poética, que son el resultado de la educación neoclásica del joven periodista. Sin que Larra los mencione, no es difícil distinguir bajo sus líneas la Poética de Luzán y la obra de Menéndez Valdés, aunque él prefiere citar modelos clásicos no españoles, como Horacio y Voltaire. Tras la exposición de esta primera teoría, Larra pasa a alabar a Martínez de la Rosa por su doble labor como preceptista $^{7}$ y como autor lírico, aunque esta última apreciación viene rebozada con la típicamente equívoca prosa que Larra emplea cuando habla de autores amigos suyos, y Martínez de la Rosa lo era. Prestemos ahora atención al siguiente punto del artículo.

«No remontemos (dice el autor en su prólogo) tan desacordadamente el concepto y la frase que cuesta trasudores el entendernos». «No recuerdo un solo rasgo sublime - dice en otra parte- en cualquiera lengua que sea, que no esté expresado con sencillez». Esta idea, adoptada por nuestro poeta y tan bien seguida en su Edipo; esta imitación de la griega sencillez, es la que distingue sus obras poéticas de las demás de su época: la oscura ampulosidad es una montaña que abruma nuestra poesía; nada más necesario que el que se resuelvan los jóvenes, en fin, a segregar del fruto precioso el lujurioso pámpano que le ahoga. No es la palabra lo sublime: séalo el pensamiento; parta derecho al corazón, apodérese de él y la palabra lo será también. (Larra, 1997: 106).

Larra suscribe las ideas de Martínez de la Rosa sobre la sencillez. Imitación de la griega sencillez, dice concretamente, en contra de la «ampulosidad». No quedaría muy claro a qué se refieren ambos autores con «griega sencillez» si no recordáramos que para Larra es crucial la formación clásica del artista, del escritor. Es por ello que Martínez de la Rosa, al imitar ese estilo «griego» no hace sino procurar conseguir lo que los escritores franceses habían venido haciendo desde Du Bellay hasta el momento con el latín y los alemanes con el griego a partir de Herder, un par de generaciones antes que la de Larra: asumir las enseñanzas estilísticas de las lenguas clásicas mediante la apropiación de sus recursos lingüísticos. Ahora bien, tanto en el caso de Du Bellay en Francia como en el de Herder en Alemania, la imitación no es el método a seguir, sino la asimilación, que deja más espacio a la originalidad del escritor. Esa es, en la perspectiva herderiana ${ }^{8}$, la manera de construir una

\footnotetext{
${ }^{7}$ Martínez de la Rosa había publicado su Poética, fuera de sus Obras (1827-1830) editadas en París, en 1831.

${ }^{8}$ Para profundizar en esta cuestión, véanse los dos primeros capítulos de The World Republic of Letters, de Pascale Casanova.
} 
literatura nacional, propósito este de los mayores desvelos para Fígaro. La educación clásica de Larra le permitió ver esta carencia en las letras españolas, en especial en la lírica, como se desprende de la explicación de Larra al estado de pobreza lírica de la literatura española que presencia y a su consejo para los poetas más jóvenes de «segregar del fruto precioso el lujurioso pámpano que le ahoga». Esta frase, en apariencia sencilla, esconde una de las grandes contradicciones de Larra como autor literario. Por una parte, apoya la existencia de una Poética que ofrezca modelos preceptivos más allá de la obra de poetas anteriores, elemento sin duda hijo de sus ideas ilustradas, pero al mismo tiempo critica duramente a la permanencia del modelo neoclásico en poesía, que queda simbolizado en ese «pámpano», en clara referencia a la poesía anacreóntica de peor inspiración, género que había venido siendo extensamente cultivado desde el siglo XVIII, más por imitación de un supuesto ambiente clásico y sus modelos que de una auténtica asimilación de poetas griegos, en el sentido de Du Bellay. Ahora bien, en ese consejo de Larra para trascender la estética de la lírica neoclásica más agotada se puede vislumbrar, si bien meramente apuntado, una tendencia de Fígaro a aceptar cada vez más el presupuesto romántico, en ciernes, del retorno a modelos griegos, como en el caso de Martínez de la Rosa. Larra continúa destacando el, en su visión, gran defecto de la poesía de su tiempo, esto es, la ampulosidad. Es aquí donde la teoría poética de Larra se identifica con la de su teoría linguiística de la necesidad de forjar un castellano auténtico, limpio y correcto, libre de extranjerismos innecesarios y de defectos consecuencia de una mala formación en letras, como condición intrínseca para la formación de una literatura española moderna y sólida. Al afirmar que lo sublime no es la palabra, sino el pensamiento, y que la forma debe ser sencilla, es quizá cuando las ideas poéticas de Larra están más en sintonía con otros poetas y teóricos románticos europeos. El mismo presupuesto lingüístico sobre la sencillez y lo excelso se encuentra en la famosa y citadísima introducción a las Lyrical Ballads que William Wordsworth antepuso a su obra al alimón con Coleridge. La ampulosidad a que se refiere Larra es el resultado de una práctica poética en que a la palabra se le otorga un rango estético en su faceta más material, mientras que para él, como para otros poetas románticos europeos ${ }^{9}$, es la pasión, el sentimiento y altura del pensamiento los que sublimizan las palabras, no viceversa, y de ahí que se defienda un estilo presidido por la sencillez de expresión. Una vez expuesta su teoría poética, prácticamente latente en estas

\footnotetext{
${ }^{9}$ Aparte de Wordsworth se pueden citar otros escritores decisivos en Europa, como Novalis en sus Himnos a la noche y su Enrique de Ofterdingen, donde se expone poéticamente su idea central de correspondencia entre macrocosmos y microcosmos, afín en buena medida a la defensa que Larra propone de la pasión y sublimidad como origen del genio poético. En cuanto a España, esta idea de Larra va a adquirir toda su relevancia en la obra de Bécquer y, de ahí, alargará su influencia hasta el siglo XX.
} 
breves líneas, Larra añade que «hay ternura en sus composiciones, sentimiento en sus versos, profundidad a veces, dulce y melancólica filosofía». Es decir, se destacan cuatro cualidades en la colección de Martínez de la Rosa: ternura, sentimiento, profundidad y filosofía. Es evidente que Larra se cura en salud frente a la obra de su amigo aduciendo que «a veces» tiene «profundidad». Pese a que este sustantivo, junto con «filosofía», es un tanto general e impresionista, lo cierto es que estas líneas nos permiten averiguar el horizonte de expectativas que Larra exige de un poeta lírico. Ahora bien, la poesía de Martínez de la Rosa presenta un fallo en opinión de Fígaro: el género que más ha privilegiado el poeta en su tomo es el género anacreóntico, de cuya ya lograda excelencia cita Larra al mismo Anacreonte, a Gessner y a Meléndez, estos dos últimos poetas plenamente del siglo XVIII. Sin duda el género anacreóntico, que en España alcanza su máximo desarrollo con los poetas neoclásicos, estaba más que agotado cuando Larra escribe esta reseña. Pero no sólo se trata de un género poético superado más, sino que es uno de los pilares del panorama poético español en que Larra se ha formado, íntegramente neoclasicista y en buena parte opuesto al principio que ahora defiende Fígaro de sublimidad de ideas más que de palabras, mientras que la estética anacreóntica no va por esos derroteros, mucho menos a mediados de la primera mitad del siglo XIX. No deja de resultar necesario recalcar que, en cuanto a concepciones literarias románticas, este rechazo a la perpetuación de un género en buena parte no romántico es una de las primeras muestras de renovación crítica literaria en las letras españolas, y la evidencia de que la teoría literaria de Larra iba más a la par de sus contemporáneos europeos, especialmente franceses, ingleses y alemanes. No en vano, Larra cita como ejemplo de lo que necesita encarnar la poesía española las obras de Lamartine y Byron, y de nuevo insiste en la necesidad de una poesía de ideas, inspiración y filosofía que estos poetas desarrollan para la renovación de una sociedad «gastada» como la española. En la concepción literaria de Larra, pues, incluso la poesía, género que como hemos visto apenas ocupa una mínima parte de su carrera como autor y crítico, debe atender a la reforma de la nación. Añadiré algo más. Larra asegura que

los versificadores que sólo hacer versos saben, mas no sentirlos, podrán tachar de poco robustos algunos del autor; nosotros, aunque conocemos la necesaria cooperación de la más completa armonía posible en la poesía, pasamos ligeramente sobre ese reproche, y siempre daremos la preferencia en todo caso a las ideas. (Larra, 1997: 107).

Esta distinción implícita entre «poeta» y «versificador» también parece una idea de transición en el pensamiento estético de Larra, pues parece alejarse de la aceptación de la necesidad de preceptistas del buen gusto, que había aprendido de la escuela neoclásica, mientras que refrenda la preocupación creciente de Larra por el contenido «filosófico» y «sentimental». En el párra- 
fo recién citado, Larra parece dar por hecho que la labor del versificador es condición indispensable para un poeta, pero que es el estadio primero, incompleto, de la escritura poética, que debe enriquecerse con ideas y echar a vivir con la pasión. No obstante, en las últimas líneas de su artículo Larra no pierde la oportunidad de recalcar y afirmar una de sus máximas reglas estéticas: el buen gusto, del que señala a Martínez de la Rosa como modelo para la juventud. Es también indicativo de su teoría poética el hecho de que alabe las composiciones elegíacas del poeta reseñado, ya que el de Larra es un modelo lírico en que el «género» va ligado a una estrofa determinada. De ahí que su sistema crítico no tolere más odas anacreónticas y sí elegías, cuando ambos «géneros» tienen pareja duración en las letras europeas. De nuevo, Larra está a caballo entre dos universos poéticos, entre clásicos y modernos. Además, en este artículo, en fin, Larra está entrando de lleno en el debate inextinguible entre forma y contenido, inspiración y regulación ${ }^{10}$, que tanta preeminencia irá ocupando durante el siglo XIX hasta la revolución del Modernismo hispánico, pero cuyos efectos preocuparon de modo incomparable a los románticos europeos. Una vez más, incluso la intuición poética de Larra le confirma como un adelantado en la crítica española de su tiempo.

La idea del retraso de la poesía en cuanto a géneros y a la necesidad de su modernización va a repetirse intermitentemente en algunos artículos de crítica teatral. El caso más obvio es quizá el del artículo Representación de "Tanto vales cuanto tienes», comedia original en tres actos y en verso de don Ángel Saavedra ${ }^{11}$. Dice Larra

Ahora bien, en el siglo XIX, siglo harto matemático y positivo; siglo del vapor, siglo en que los caminos de hierro pesan sobre la imaginación, como un apagador sobre una luz, en que Anacreonte, con su barba bañada de perfumes, Petrarca, con sus eternos suspiros, y aun Meléndez con todas sus palomas, harían un triste papel al lado, no de un Rotschild o un Aguado, pero aún de un mediano mecánico, que supiese añadir un resorte a cien resortes anteriores. (Larra, 1997: 214).

Es evidente que la modernidad es para Larra fruto de una edad nueva inaugurada por la revolución industrial, y la idea del progreso como algo no sólo efectivamente real sino deseable. Y esto no puede ser menos para la lírica, en la que la repetición de los consabidos temas neoclásicos tratados en la anacreóntica (Meléndez) y en la poesía amorosa galante (cita a Petrarca) no es la dirección apropiada para una renovación de la lírica, sino que esta pasa por una modernización literal, al estilo de la tecnológica, en que nuevas formas deben corresponder a lo nuevos talentos, y no por una perpetuación temática y formal que, como mucho, haría al poeta comparable a ese «mediano mecánico», espí-

${ }^{10}$ Algunas décadas más tarde, Bécquer se ocupará del tema de forma poética en varias de sus rimas, en especial las rimas III y XXVI.

${ }^{11}$ Publicado en Revista Española, núm. 260. Madrid, 6 de julio de 1834. 
ritu de la mediocridad de los nuevos tiempos, que no sabe crear sino reprodu$\operatorname{cir}^{12}$. Larra escribió otra crítica sobre poesía lírica. Se trata de su artículo Poesías de don Juan Bautista Alonso ${ }^{13}$, en que Larra repite algunos de los presupuestos apuntados en la crítica de las Poesías de Martínez de la Rosa, pero en un tono mucho más combativo. En esta ocasión Larra dedica tres largos párrafos en que va de lo general a lo particular en cuanto al estado de decadencia literaria del país, desde la libertad de imprenta hasta el estancamiento de la poesía lírica. Parece que esta primera parte del artículo fuera dirigida a amortiguar lo que parece ser una opinión no tan favorable de la obra de Alonso, a pesar de que en la superficie del texto el juicio parece ser positivo. En primer lugar, hay que destacar el hecho de que Juan Bautista Alonso era amigo de Larra y parroquiano de la tertulia del Príncipe a la que acudía Fígaro. Y no sólo eso. Alonso era pasante al servicio del abogado Manuel Cambronero, padre de José María Cambronero, esposo de Dolores Armijo, amante de Larra. De hecho, es este artículo el único de Fígaro en que aparece el nombre de Dolores. Sabemos poco de la relación entre Larra y Alonso, pero los datos de que disponemos ${ }^{14}$ parecen apuntar a una relación estrecha de íntima amistad, que justificaría el estilo más o menos cortés, de cumplido, que emplea Larra en la crítica de los versos de su amigo, que, muchos años después, diría a Galdós de Larra que este tenía un «humor hipocondríaco»y «bruscas oscilaciones de un ánimo arrebatado». Pero volvamos a la reseña:

Nuestro Siglo de Oro ha pasado ya, y nuestro siglo XIX no ha llegado todavía. En poesía estamos aún a la altura de los arroyuelos murmuradores, de la tórtola triste, de la palomita de Filis de Batilo y Menalcas, de las delicias de la vida pastoril del caramillo y del recental, de la leche y de la miel, y otras fantasmagorías por este estilo. En nuestra poesía a lo menos no se hallará malicia: todo es pura inocencia. Ningún rumbo nuevo, ningún resorte no usado. Convengamos en que el poeta del año 35, encenagado en esta sociedad envejecida, amalgama de oropeles y de costumbres perdidas, presa él mismo de pasioncillas endebles, saliendo de la fonda o del billar, de la ópera o del sarao, y a la vuelta de esto empeñado en oír desde su bufete el cefirillo suave que juega enamorado y malicioso por entre las hebras de oro o de ébano de Filis, y pintando a la Gessner la deliciosa vida del otero (invadido por los facciosos), es un ser ridículamente hipócrita, o furiosamente atrasado. ¿Qué significa escribir cosas que no cree ni el que las escribe ni el que las lee? (Larra, 1997: 309).

Es este uno de los más finos y directos ataques al estado de la poesía española que escribiera Larra y, al mismo tiempo, podemos extraer de este

${ }^{12}$ Son numerosos los artículos en los que Larra ataca veladamente la escritura mecánica de odas, anacreónticas y otras estrofas clásicas. Véanse, a modo de ejemplo, los artículos «Don Timoteo o el literato»; «La fonda o la prisión de Rochester»; «Segunda carta de un liberal de acá»; «Tercera carta de un liberal de acá».

${ }^{13}$ Publicado en Revista Española, núm. 484. Madrid, 19 de febrero de 1835.

${ }^{14}$ Véase Larra y España, donde Varela da noticia de Alonso. 
párrafo algunas ideas más para acabar de perfilar el sistema poético de Fígaro. En primer lugar, en la crítica de Larra la poesía española aparece atrasada respecto de su tiempo, del mismo modo que la sociedad, la política y las otras artes en la península. Se vuelve a incidir en la idea y temas del estilo neoclásico ya gastados y perpetuados por poetas sin talento. Pero, sobre todo, lo que de modo indirecto propone Larra es una lírica activa, hija de su tiempo, consciente de la historia y sociedad en que se genera, y denuncia la actitud «hipócrita» del conjunto general de los poetas. Si en el artículo dedicado a las Poesías de Martínez de la Rosa Larra mencionaba la «pasión» como ingrediente necesario en la práctica poética, aquí ataca ahora las «pasioncillas endebles» que nacen a consecuencia de su «sociedad envejecida», donde los lugares públicos de inspiración del poeta no pueden de ningún modo relacionarse con la Arcadia neoclásica, sino con la sordidez de ciertos ambientes urbanos del XIX, tales como la fonda, el billar, la ópera y el sarao. En otras palabras, Larra denuncia el escapismo como estilo lírico porque no responde a su amplia proposición de reforma social, en la cual los escritores, incluidos los poetas, deberían buscar sus temas y formas en la sociedad contemporánea a través de una literatura útil y progresiva ${ }^{15}$. También como en el artículo sobre Martínez de la Rosa, Larra censura la continuación de la poesía de Meléndez y de Gessner, y vuelve a proponer los modelos de Lamartine y Byron. La actitud de Larra es pesimista ante el desarrollo de la lírica, porque comprueba que la «antigua escuela» (la neoclásica) sigue ejerciendo su imperio sobre los poetas que, de ningún modo, podrían ser neoclásicos pero que se empeñan en atrasar su obra para protegerla bajo la égida de la última generación consagrada de poetas en España. Así, Larra se pregunta: «Todo va despacio entre nosotros, ¿por qué ha de ir deprisa sólo la poesía?» A pesar de que Larra insiste en que sus consideraciones negativas nada tienen que ver con el tomo de Alonso, lo cierto es que la poesía de este se enmarca en la clase de poesía que Fígaro acaba de censurar unas pocas líneas antes de comenzar el análisis en sí del tomo de poemas de su amigo. Así, el libro de Alonso se divide «según la antigua clasificación», en frase donde sabemos que «antigua» es en Larra sinónimo ya de «no válida». Presumiblemente, la obra de Alonso consta de odas, bajo las que Larra vislumbra «discursos», quizá atacando lo prosaico de la labor técnica del poeta, y los poemas son enumerados por la estrofa en que están compuestos: sonetos, letrillas, anacreónticas... En resumen, el tipo de poemario que no gusta a Larra. Sin duda, Fígaro está encadenado por la amistad a aligerar su crítica literaria, pues debe dejar bien a un libro que le parece mal. Pueden citarse multitud de ejemplos del estilo excusatorio

\footnotetext{
${ }^{15}$ Adjetivos estos con que describe Larra la literatura española que no fue, en su artículo «Literatura. Rápida ojeada sobre la historia e índole de la nuestra. Su estado actual. Su porvenir. Profesión de fe». A él remito para una teoría literaria de Larra en su sentido más amplio, que sobrepasa el objeto de este estudio, las ideas sobre poesía lírica de Fígaro.
} 
que Larra no puede sino emplear: «La oda elegíaca que sigue está salpicada de poesía por todas partes: es a la muerte de una joven hermosa recién casada. Imágenes atrevidas, símiles felicísimos, sentimiento alguna vez». Decir de una oda que está «salpicada de poesía» es como decir que no la tiene y que de vez en cuando se distingue algo de poesía. En cuanto a las «imágenes atrevidas» y los «símiles felicísimos», no es difícil apreciar lo tibio de tales adjetivos. Analizando la misma oda, Larra añade: «Quítensele a esas estrofas algún adjetivo inútil, y cierta oscuridad que resulta de la violenta colocación del tercer verso de la segunda, y es un rasgo de primer orden». Aquí podemos establecer la técnica que emplea Larra para criticar negativamente con apariencia de juicio positivo, que consiste en lo que yo llamo una gramática favorable con un léxico implacable. Al releer la recomendación de Larra es imposible no percibir lo atroz de su crítica: si seguimos el consejo de Fígaro y eliminamos los elementos de que habla, desaparece el poema entero, operación que él tan cínicamente llama «rasgo de primer orden». Así, el mérito del poema sería su desaparición. En este mismo párrafo, también encontramos, por oposición, los elementos necesarios para una poética moderna en los términos de Larra. Donde se denuncia la adjetivación «inútil» la «oscuridad»y la «violenta colocación» se predica la sencillez y la claridad de que hablaba el crítico respecto de Martínez de la Rosa. Veamos otro ejemplo, inmediato al anterior, de esta técnica de Larra:

Como imitación de San Juan de la Cruz, la oda a la profesión religiosa de la señorita madrileña tiene todo el mérito de hallarse bien tomado el tono de esta clase de composiciones: hay unción, hay aquel dialecto figurado y simbólico que han usado todos los poetas de este género. (Larra, 1997: 310-311).

De nuevo, bajo una apariencia sintáctica amable, el mordisco crítico implícito. Se trata de una oda, «género» a cuya repetición, bien sabemos, se opone Larra, que dice de la composición de Alonso que su tono corresponde al de «esta clase de composiciones», y que su «unción» y «dialecto» es la que «han usado todos los poetas de este género. En resumidas cuentas, que la composición de Alonso no tiene nada de original, y que la distancia entre la figura gigantesca de San Juan de la Cruz y el tema tan frívolamente escogido son una muestra más de ese pensar que son las palabras las que tienen pasión, y no el genio del poeta. Lo que aquí denuncia Larra es la poesía de circunstancias, que tan mal parada sale en el espectro crítico de Larra. Y si la poesía de Alonso carecía de aquel elemento fundamental para Fígaro de la sencillez, también carece de filosofía, otro de los pilares de la propuesta teórico-lírica de nuestro autor:

Parécenos, sin embargo, que el género filosófico no es el sol de Austerlitz para el señor de Alonso: le comparamos con Meléndez, de quien las odas y los discursos, salvo alguna excepción como la de «las artes y las estrellas», no son lo que le da inmortalidad. El género del señor Alonso es el género mismo de 
Meléndez, el bucólico; tiene composiciones enteras dignas de Batilo. (Larra, 1997: 311).

De nuevo la sintaxis amablemente implacable. Las comparaciones con Napoleón y con Meléndez no hacen sino palidecer aún más la composición de Alonso. Por otro lado, si se afirma que el género de Alonso es el mismo de Meléndez, esto es, la bucólica, y los primeros párrafos del artículo se han dedicado a desmontar la posibilidad de que la lírica contemporánea imitadora de ese estilo dieciochesco es, cuando menos, hipócrita, ¿cómo ni siquiera aceptar la posibilidad de que Larra esté realmente alabando la labor poética de Alonso? Pero la ironía de Larra va a hacerse más cruel en las próximas líneas:

Ya no hay aquella dureza, aquella confusión de epítetos superabundantes, aquella especie de oscuridad, aquella afectada profundidad, aquel lujo pampanoso de poesía y de ruido que se advierte en sus primeras composiciones. (Larra, 1997: 311).

De nuevo se vuelve a incidir en la «oscuridad» y «lujo pampanoso» como defectos a evitar por el poeta moderno, fallos ya apuntados en el artículo sobre Martínez de la Rosa. Pero Alonso no sólo peca de esos defectos, sino que al haber dado muestra de una «afectada profundidad» está dejando en evidencia sus dotes poéticas, pues la «profundidad», rasgo requerido en el sistema lírico de Larra, no se ha conseguido, y esto, más que un defecto, es para Larra una falta de talento poético. Fígaro destaca de todo el volumen de poemas la composición «A la vida feliz», y de ella nos dice: «una vez leído ese lindo rasgo de poesía le aconsejamos que, en lugar de pasar a leer ninguna otra composición, la vuelva a leer segunda vez, y no salga de ella jamás». Larra lo puede decir más alto pero no más claro. El resto de la reseña prolonga los elementos que ya he estudiado hasta aquí. Hasta este momento, Larra solo ha escrito dos artículos de crítica poética ${ }^{16}$. Después de la reseña de las Poesías de Alonso, no será hasta casi año y medio más tarde que Larra publicará su artículo «Blanca». Cuento romántico en verso, original de don J.F. Díaz. Reflexiones acerca de nuestra poesía moderna. Poetas jóvenes que más se distinguen ${ }^{17}$. Este será el tercer y último artículo que dedicó Larra directa y exclusivamente a la poesía lírica. A pesar de que se presenta como una reseña, lo cierto es que Fígaro no se dedica tanto a analizar el cuento en verso del poeta Díaz como a dar un panorama general de modelos de poetas modernos que más se acercan a la teoría lírica de Larra y que reúnen las carac-

${ }^{16}$ No podemos contar como tal el artículo «Espagne poetique», publicado en Revista Española, núm. 197, en Madrid el 24 de abril de 1834 (es decir, entre el artículo sobre las Poesías de Martínez de la Rosa y el artículo sobre Juan Bautista Alonso) ya que no se trata de una obra lírica original, sino de una antología de poesía española en francés. De todos modos, dicho artículo no ofrece ideas que no se encuentren en los dos artículos ya analizados.

${ }^{17}$ Publicado en El Español, núm. 246. Madrid, 3 de julio de 1836. 
terísticas que hasta aquí he analizado. La mayor parte de él recalca dos males de la lírica que Larra ya había identificado con anterioridad: la nula validez de la poesía de circunstancias y el atraso de la imitación de modelos neoclásicos, en especial del género bucólico. Lo que añade este texto es una encarnación, al fin, de los ideales poéticos de Larra en figuras concretas del panorama de su tiempo a través de una reflexión sobre el cuento en verso romántico ${ }^{18}$, género a que pertenece la obra reseñada. Larra inaugura su catálogo de poetas españoles modernos que cultivan el cuento en verso con José de Espronceda, que es ejemplo de las virtudes que Fígaro exige a un buen poeta: no sólo «canturía», es decir, maestría formal rítmica, sino «tendencia filosófica y política». En otras palabras, ideas y actualidad, compromiso con la realidad de su tiempo, como hemos visto que exigía Fígaro en los artículos ya estudiados. Las composiciones que cita Larra son buena muestra de estos ideales: las canciones del Pirata, El mendigo y El reo de muerte, composiciones en que Espronceda parece elevarse, al fin, de la tan extendida y vituperada imitación neoclásica de casi todos sus contemporáneos. La nómina la completan autores que no han pasado la criba del tiempo tan sanamente como Espronceda: el poeta Ochoa, el poeta Madrazo y el poeta Romero. Es justo al final del artículo, cuando Larra ofrece a Díez algunos consejos de naturaleza técnica y prosódica, que se destaca la idea del conocimiento como fuente de poesía. Lo que hasta ahora Larra había denominado, de forma un tanto general, «filosofía», necesaria en todo buen poeta, ahora se llama «saber», en armonía con lo «útil»:

(...) puesto que es romántico, que nutra su entendimiento con copiosa lectura, porque le añadiremos que no consiste el romanticismo en usar de versos quebrados, y en adornar con descripciones de usos de los siglos medios los partos de su ingenio. El espíritu del siglo, inclinándose hacia lo positivo y lo realmente útil, exige cada vez más saber en el poeta verdades importantes y profundas, admoniciones provechosas a la sociedad regenerada; he aquí lo que es preciso poner en música poética: no sentimientos fútiles y pasajeros. La nueva escuela es la que verdaderamente trata de realizar la antigua máxima del clásico Horacio, y ahora más que nunca es el saber mucho la fuente de escribir bien. (Larra, 1997: 693).

El concepto de «profundidad» que aparecía por primera vez de forma vaga en la reseña sobre Martínez de la Rosa ahora se completa con el sustantivo «verdad». Es decir, ahora la poesía debe ser también instrumento portador de verdades, con lo que se ensalza la dimensión moral que a Larra le parece

${ }^{18}$ Este género poético-narrativo causó furor en toda Europa. No sólo los cuentos en verso de Byron, de entre los que Mazzeppa es quizá el mayor ejemplo, sino buena parte de la obra de Espronceda que Larra no pudo conocer completamente (El Diablo Mundo) las Leyendas de Zorrilla, la novela en verso Eugenio Onegin, de Pushkin... El género derivaría en la prosa poética de Bertrand y Baudelaire en Francia, inaugurando un género poético que ha llegado a nuestros días. 
necesaria incluso en el género lírico. Por otra parte, parece por fin claramente sancionar la poesía romántica de la «nueva escuela» que va a adoptar el, para Larra, modelo clásico por antonomasia de construcción poética: el saber como pasión poética, como origen de las «verdades» líricas. De este modo parecen combinarse las ideas ilustradas sobre la educación y el nuevo ideal romántico en su vertiente más ligada a la sociedad, a la regeneración de las naciones. En este texto, Larra ha hecho un avance de peso: si cuando reseñaba los poemas de Martínez de la Rosa exigía al poeta que tuviera «sentimiento», aquí matiza esa opinión y asevera que el «sentimiento» no puede ser ligero (adjetivo que caracterizaba a la poesía de imitación neoclásica) sino que debe proceder de la conjunción del conocimiento, la verdad, y la inspiración instructora. En conclusión, al atender a este limitado número de textos en que Larra construye su teoría de la lírica se completa la visión que tenemos de la relación de Larra con la literatura de su tiempo, su sistema para regenerarla, su ojo crítico para distinguir las carencias del género lírico y de la literatura española en general, al mismo tiempo que podemos comprobar como dichas ideas sobre la poesía están en perfecta consonancia y plausibilidad con la crítica ejercida sobre los otros géneros, creando toda una poética coherente en que talento, conocimiento, reforma social, preparación técnica, profesionalización e innovación temática y tonal suponen el programa que Larra ofrece a los escritores (y poetas) de su tiempo. Ahora sería el momento de establecer una comparación entre la breve obra poética de Fígaro y sus propios artículos de crítica poética para medir el grado de fracaso con que él mismo llevo a cabo sus teorías, y apuntar a las razones que le llevaron a abandonar su labor como poeta, esa gracia que no quiso darle el cielo.

\section{BIBLIOGRAFÍA CITADA}

Aranguren, José Luis L. (1976). Estudios literarios. Madrid: Gredos.

Armiño, Mauro (1973). Qué ha dicho verdaderamente Larra. Madrid: Doncel.

Aymes, Jean René (1983). Revisión de Larra: ¿Protesta o revolución? París: Les belles lettres.

Bécquer, Gustavo Adolfo (1989). Rimas y leyendas. Barcelona: Promociones y Publicaciones Universitarias.

Casanova, Pascale (2007). The World Republic of Letters. Cambridge, Mass.; London: Harvard University Press.

Escobar, José (1973). Los orígenes de la obra de Larra. Madrid: Prensa Española.

Kirkpatrick, Susan (1977). Larra, el laberinto inextricable de un romántico liberal. Madrid: Gredos.

Larra, Mariano José de (1997). Fígaro. Colección de artículos dramáticos, literarios, políticos y de costumbres. Barcelona: Crítica.

Larra, Mariano José de (1980). Diccionario privado de Mariano José de Larra. Madrid: Altalena.

Lorenzo-Rivero, Luis (1986). Estudios literarios sobre Mariano J. de Larra. Madrid: J. Porrúa Turanzas. 
Martínez Ruiz «Azorín», José (1921). Larra: razón social del romanticismo en España. Madrid: Caro Raggio.

Novalis (1964). Henry von Ofterdingen. New York: F. Ungar.

Novalis (1978). Hymns to the Night. New York: Treacle Press.

Romero Mendoza, Pedro (1960-63). Siete ensayos sobre el romanticismo español. Cáceres: Diputación Provincial.

Ruiz Otín, Doris (1983). Política y sociedad en el vocabulario de Larra. Madrid: Centro de Estudios Constitucionales.

Schurlknight, Donald E. (2009). Power and dissent. Larra and Democracy in nineteenthcentury Spain. Lewisburg: Bucknell University Press.

Sherman, Alvin F. (1992). Mariano José de Larra. A directory of historical personages. New York: P. Lang.

Varela, José Luis (1983). Larra y España. Madrid: Espasa-Calpe.

Wordsworth, William (2002). Lyrical Ballads and related writings. Boston: Houghton Mifflin.

Fecha de recepción: 4 de febrero de 2011

Fecha de aceptación: 3 de octubre de 2011 